\title{
Efficacy of native isolates of Metarhizium anisopliae and Beauveria bassiana against the invasive ambrosia beetle, Xylosandrus germanus Blandford (Coleoptera: Curculionidae: Scolytinae)
}

\author{
Celal Tuncer, Rahman Kushiyev* (D), Ismail Erper, Ismail Oguz Ozdemir and Islam Saruhan
}

\begin{abstract}
The invasive ambrosia beetle, Xylosandrus germanus Blandford (Coleoptera: Curculionidae: Scolytinae), is one of the most significant pests in hazelnut orchards in Turkey. Chemical control of the beetle is very difficult, because it spends the majority of its life in the sapwood of host trees. In this study, entomopathogenic fungi (EPF), Metarhizium anisopliae (TR106 isolate), and Beauveria bassiana (TR-217 isolate) were tested against the female adults of X. germanus under laboratory conditions by two different methods. In the first method, conidial concentrations $\left(1 \times 10^{6}\right.$ and $1 \times 10^{8}$ conidia ml $\left.^{-1}\right)$ of the fungal isolates were directly applied to the beetles in Petri dishes ( $2 \mathrm{ml}$ per dish), using a Potter spray tower. In the second method, the same conidial concentrations were applied on a sterile hazelnut branch placed in the Petri dishes, and then, beetles were released in dishes. The Petri dishes were incubated at $25 \pm 1{ }^{\circ} \mathrm{C}$ and $75 \pm 5 \% \mathrm{RH}, 16: 8$-h light:dark photoperiod. Lethal time values $\left(\mathrm{LT}_{50}\right.$ and $\left.\mathrm{LT} T_{90}\right)$ for the isolates were calculated, using Probit analysis. As a result, $\mathrm{LT}_{50}$ and $\mathrm{LT}_{90}$ values of $M$. anisopliae isolate at $1 \times 10^{8}$ conidia $\mathrm{ml}^{-1}$ were 4.43 and 6.01 days, respectively, at the beetle application method and 3.97 and 5.68 days, respectively, at the branch application method. $L T_{50}$ and $L T_{90}$ values were

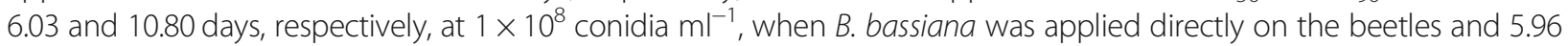
and 11.79 days at the same concentration, when it was applied on the branch application method. $M$. anisopliae at $1 \times$ $10^{8}$ conidia $\mathrm{ml}^{-1}$ caused $100 \%$ mortality rate at the end of the 8th day in the two application methods. The mortality rates when applying $1 \times 10^{8}$ conidia $\mathrm{ml}^{-1}$ of B. bassiana recorded $64 \%$ and $80 \%$ by the end of the 8 th day on branch and insect application methods, respectively. The efficiency of $1 \times 10^{6}$ conidia $\mathrm{ml}^{-1}$ of the isolates was lower than $1 \times$ $10^{8}$ conidia $\mathrm{ml}^{-1}$ against $X$. germanus in both application methods. This study showed that the isolates of TR-106 and TR-217 had a significant potential as biological control agents against $X$. germanus.
\end{abstract}

Keywords: Xylosandrus germanus, Entomopathogenic fungi, Hazelnut, Turkey

\section{Background}

Ambrosia beetles (Coleoptera: Curculionidae: Platypodinae and Scolytinae) are very important pests on many trees (Hulcr and Dunn 2011). They are wood boring insects that make tunnels through sapwood of trees and feed primarily on symbiotic fungi living in the tunnels (Knížek and Beaver 2007). Adults and larvae feed solely

\footnotetext{
* Correspondence: rahmankushiyev@gmail.com

Faculty of Agriculture, Department of Plant Protection, Ondokuz Mayis University, 55139 Samsun, Turkey
}

\section{Springer Open}

(c) The Author(s). 2019 Open Access This article is distributed under the terms of the Creative Commons Attribution 4.0 International License (http://creativecommons.org/licenses/by/4.0/), which permits unrestricted use, distribution, and reproduction in any medium, provided you give appropriate credit to the original author(s) and the source, provide a link to the Creative Commons license, and indicate if changes were made.

with the fungi, except in some species where larvae also ingest fungus-infested wood (Biedermann 2007).

Turkey is the world's biggest hazelnut producer, supplying nearly $80 \%$ of the total global production. Ambrosia beetles including Anisandrus dispar Fabricius, Xyleborinus saxesenii Ratzeburg, and Xylosandrus germanus Blandford are widespread pests on hazelnut trees in Turkey. Due to their damage, most of the hazelnut trees die finally, especially in orchards at Black Sea coastline in which the ground water level is high (Ak 2016). X. germanus was firstly detected in Turkish hazelnut orchards in 2011 
(Knižek 2011) and became one of the major pests in hazelnut orchards with other ambrosia beetles. Afterwards, it was recorded as a pest of kiwi trees in Black Sea Region of Turkey (Ak et al. 2011).

Control methods against these ambrosia beetles, including $X$. germanus in hazelnut orchards, depend on the use of conventional insecticides against emerged adults, cultural methods (pruning and removing infested branches of trees), and mass trapping of emerged adults through red winged ethanol-baited sticky traps. When insecticide spraying is needed for control, it is necessary to use as many as $6-7$ applications because of the beetle's long prevalence periods in orchards. But, chemical control is obviously unpractical due to its detrimental effects, high cost, and low efficacy in such a large area of hazelnut plantations. For this reason, there is a need for more effective and ecologically safe alternative control methods. Using EPF may have a potential to suppress the ambrosia beetles (Arthurs and Bruck 2017).

EPF are common natural enemies of arthropods worldwide, attracting attention as potential biological control agents. They are more than 700 species (Roy et al. 2006). EPF such as Beauveria bassiana (Bals.) Vuill., Isaria fumosorosea Wize, Lecanicillium spp., and Metarhizium anisopliae (Metch) Sorokin play an important role in the regulation of insect populations (Zimmermann 2007a, 2007b and 2008). Previous studies have showed that they were effective on ambrosia beetles including, X. germanus, A. dispar, Xylosandrus crassiusculus Motschulsky, and Xyloborus glabratus Eichhoff (Castrillo et al. 2013; Carrillo et al. 2015; Kushiyev et al. 2018). Kushiyev et al. (2018) determined that I. fumosorosea at $1 \times 10^{8}$ conidia ml $\mathrm{ml}^{-1}$ against female adults of $X$. germanus applied on adults and on branches caused 100 and $90 \%$ mortality rates, respectively. EFP may affect not only adults outside the host trees but also larvae inside the beetle galleries (Castrillo et al. 2013).

The aim of the present was to evaluate the efficacy of two conidial concentrations $\left(1 \times 10^{6}\right.$ and $1 \times 10^{8}$ conidia $\mathrm{ml}^{-1}$ ) of $M$. anisopliae (TR-106) and B. bassiana (TR-217) against the females of X. germanus, using two different application methods.

\section{Material and methods}

\section{Isolation of EPF}

The EPF, M. anisopliae (TR-106) and B. bassiana (TR-217), isolates used in this study were obtained from female cadavers of $X$. germanus collected from hazelnut orchards in Samsun provinces in Black Sea Region in Turkey. The cadavers were observed under a Leica EZ4 stereomicroscope at $\times 40-70$ magnification for fungal growth, and a piece of fungal mat was transferred to water agar (WA) by a sterile needle. The cultures were incubated for $3-5$ days at $25 \pm 1{ }^{\circ} \mathrm{C}$ and $75 \pm 5 \% \mathrm{RH}$ under 16: 8-h L:D photoperiods. Mycelial tips were cut from the edge of the 5-day-old fungal colonies, transferred to 2\% malt extract agar (MEA) (Merck), and incubated for a period of 10-14 days under the same conditions. Single-spore isolates were obtained by serial dilution (Dhingra and Sinclair 1995), and the fungi were identified as M. anisopliae and B. bassiana according to Samson et al. (1988) and Humber (1997). The cultures were stored at $4{ }^{\circ} \mathrm{C}$ on Sabouraud Dextrose Agar (SDA) (Merck Ltd., Darmstadt, Germany) slants and $-80^{\circ} \mathrm{C}$ in cryogenic tubes containing $15 \%$ glycerol and deposited in the fungal culture collection of the Mycology Laboratory at the Ondokuz Mayis University, Faculty of Agriculture's Department of Plant Protection in Samsun, Turkey.

\section{Collection of insects}

Hazelnut orchards in Samsun province (Turkey) were inspected to collect hazelnut branches infested with $X$. germanus during May 2016. Infested branches with beetles were cut $(40-\mathrm{cm}$ long) in the field, placed in plastic containers $(20 \times 25 \times 40 \mathrm{~cm})$, and then brought to the laboratory. Infested branches were dissected by pruning scissors, and females were collected from galleries. Collected females were inspected under the Leica EZ4 stereomicroscope at $\times 40-70$ magnification to separate the healthy $X$. germanus females in order to use them in bioassays. Like other ambrosia beetles, males of $X$. germanus are in very low sex ratio (about 10:1), flightless, and rarely seen outside the gallery. Thus, females were used in the tests of the study (Ranger et al. 2016).

\section{Inoculum of entomopathogenic fungi isolates}

The isolates of $M$. anisopliae (TR-106) and B. bassiana (TR-217) were propagated on SDA at $25 \pm 1{ }^{\circ} \mathrm{C}$ and $75 \pm$ $5 \% \mathrm{RH}$ for 15 days. Conidia were harvested by sterile distilled water containing $0.02 \%$ Tween 20 . Mycelia were removed by filtering conidia suspensions through four layers of sterile cheesecloth. The concentrations of conidia were adjusted to both $1 \times 10^{6}$ and $1 \times 10^{8}$ conidia $\mathrm{ml}^{-1}$, using a Neubauer hemocytometer under Olympus CX31 compound microscope (Olympus America Inc., Lake Success, NY, USA) for each isolate (Kushiyev et al. 2018).

\section{Assessment of conidial viability}

The viability of conidia of the 2 isolates (TR-106 and TR-217) was determined by spreading $0.1 \mathrm{ml}$ of concentration of $1 \times 10^{4}$ conidia $\mathrm{ml}^{-1}$ on 3 separate 6-cm-diameter Petri dishes containing Potato Dextrose Agar (PDA: Oxoid Ltd., Basingstoke, UK) and incubating them at $25 \pm 1{ }^{\circ} \mathrm{C}$ for $24 \mathrm{~h}$ under a 14:10-h L:D photoperiod. After $24 \mathrm{~h}$ of incubation, germination was determined by counting 200 conidia/dishes with an Olympus 
CX-31 compound microscope at $\times 400$ magnification. Conidia were regarded as germinated when they produced a germ tube at least half of the conidial length (Kushiyev et al. 2018).

\section{Virulence of the EPF versus $X$. germanus females}

The experiments were carried out in 2 main tests. In the first, the conidial concentrations $\left(1 \times 10^{6}\right.$ and $1 \times 10^{8}$ conidia $\mathrm{ml}^{-1}$ ) of TR-106 and TR-217 isolates were applied separately versus the females of $X$. germanus $(2 \mathrm{ml}$ per dish), using a Potter spray tower (Burkard, Rickmansworth, Hertz, UK) and one sterilized hazelnut branch (5 $\mathrm{cm}$ length and $1 \mathrm{~cm}$ in diameter) was added in each Petri dish. In the second test, the same concentrations of the isolates were sprayed on sterilized hazelnut branches in Petri dishes, and afterwards, the beetles were released on them. Another group of sterilized hazelnut branches was sprayed with sterile distilled water containing $0.02 \%$ Tween $20(2 \mathrm{ml})$ for the control experiments. Petri dishes were loosely covered by a Parafilm after applications. Females of $X$. germanus were surface sterilized with $70 \%$ ethanol for $10 \mathrm{~s}$ before the experiments (Castrillo et al. 2013). The hazelnut branches used in the experiments were autoclaved in autoclavable polyethylene bags $(30 \times 30 \mathrm{~cm})$ for $1 \mathrm{~h}$ at $121^{\circ} \mathrm{C}$ on 2 successive days. The Petri dishes lined with moist filter paper $(9 \mathrm{~cm}$ in diameter) at the bottom were used in all experiments. The spray tower was cleaned with $70 \%$ ethanol and sterile distilled water after each application of the fungus concentrations for disinfecting the apparatus. For 8 successive days of experimental observations, different groups of insects were used in 5 replications by 5 insects per Petri dish ( $n=25$ insects/day/concentration/application method) and so provided independence of the observations on the mortality on over time (Robertson et al. 2007). The same procedure was followed up at the control groups. Different control groups were set for each observation daily. Petri dishes were incubated at $25 \pm 1{ }^{\circ} \mathrm{C}$ and $95 \% \mathrm{RH}, 16$ :8-h light:dark photoperiod for 8 days in a BINDER incubator (Model KBWF 240,
Germany). All dishes of each observation were inspected daily during 8 days, percent mortality was calculated on each observation day independently, and alive insects were discarded. Dead individuals in which the fungal sporulation is observed were counted under the Leica EZ4 stereo microscope at $\times 40-70$ magnification.

\section{Statistical analysis}

Independent-time mortality data from bioassays were analyzed by probity analysis program (POLO-PLUS Ver.2.0) to calculate $50 \%$ lethal time $\left(\mathrm{LT}_{50}\right)$ and $90 \%$ lethal time $\left(\mathrm{LT}_{90}\right)$. In lethal time analysis, Log-Probit analysis calculations were considered in the program. Slopes of regression lines were compared to each other by their standard errors. $\mathrm{LT}_{50}$ and $\mathrm{LT}_{90}$ values of two application methods and two conidial concentrations were compared based on overlapping of $95 \%$ fiducial limits.

\section{Results and discussion}

Conidial viability of $M$. anisopliae (TR-106) and B. bassiana (TR-217) was assessed before bioassays, and almost $100 \%$ of the conidia of the isolates germinated at the end of the $24 \mathrm{~h}$. The results showed that the 2 isolates were pathogenic to females of $X$. germanus in the 2 different tested concentrations $\left(1 \times 10^{6}\right.$ and $1 \times 10^{8}$ conidia $\left.\mathrm{ml}^{-1}\right)$ and application methods (on branch and direct on insect).

Considering the application method, a significant difference was observed between the 2 concentrations of the isolate (TR-106) applied to $X$. germanus $(P<0.05)$. The concentration $\left(1 \times 10^{8}\right.$ conidia $\left.\mathrm{ml}^{-1}\right)$ was more effective than the other on $X$. germanus at both application methods (branch and insect). Following application with $1 \times 10^{6}$ conidia $\mathrm{ml}^{-1}$ of the TR-106 isolate of $M$. anisopliae, the $\mathrm{LT}_{50}$ value for $X$. germanus was 5.45 and 6.67 days, respectively, for branch and insect applications. Respective values at $1 \times 10^{8}$ conidia $\mathrm{ml}^{-1}$ were 3.97 and 4.43 days, respectively. However, the $\mathrm{LT}_{90}$ values for $1 \times 10^{6}$ conidia ml ${ }^{-1}$ of TR-106 isolate were 10.41 and 11.25 days, while the same values for $1 \times 10^{8}$ conidia $\mathrm{ml}^{-1}$ of the isolate were 5.68 and 6.01 days for

Table 1 Probit analysis data on mortality time of Xylosandrus germanus females after applications of two conidial concentrations of Metarhizium anisopliae TR-106 isolate on hazelnut branches and beetle females

\begin{tabular}{|c|c|c|c|c|}
\hline \multirow[t]{2}{*}{ Variables } & \multicolumn{2}{|l|}{$1 \times 10^{6}$ conidia $\mathrm{ml}^{-1}$} & \multicolumn{2}{|c|}{$1 \times 10^{8}$ conidia $\mathrm{ml}^{-1}$} \\
\hline & On branch & On insect & On branch & On insect \\
\hline $\mathrm{LT}_{50}$ (95\% fiducial limit) & $5.45(4.85-6.21) b^{*}$ & $6.67(6.06-7.59)$ b & $3.97(3.49-4.41)$ a & $4.43(4.10-4.73) \mathrm{a}$ \\
\hline $\mathrm{LT}_{90}$ (95\% fiducial limit) & $10.41(8.54-14.88) b$ & 11.25 (9.34-16.17) b & $5.68(5.04-6.90)$ a & $6.01(5.55-6.76) \mathrm{a}$ \\
\hline Slope \pm SE & $4.56 \pm 0.68 b$ & $5.63 \pm 0.99 b$ & $8.25 \pm 1.06 \mathrm{a}$ & $9.66 \pm 1.35 \mathrm{a}$ \\
\hline Regression equation & $y=-3.36+4.56 x$ & $y=-4.64+5.63 x$ & $y=-4.94+8.25 x$ & $y=-6.24+9.66 x$ \\
\hline$x^{2}$ & 41.89 & 23.04 & 67.99 & 22.70 \\
\hline$D_{f}$ & 38 & 38 & 38 & 38 \\
\hline Heterogeneity & 1.10 & 0.61 & 1.79 & 0.60 \\
\hline
\end{tabular}

*Within rows, means followed by the same lower case letters do not differ significantly 


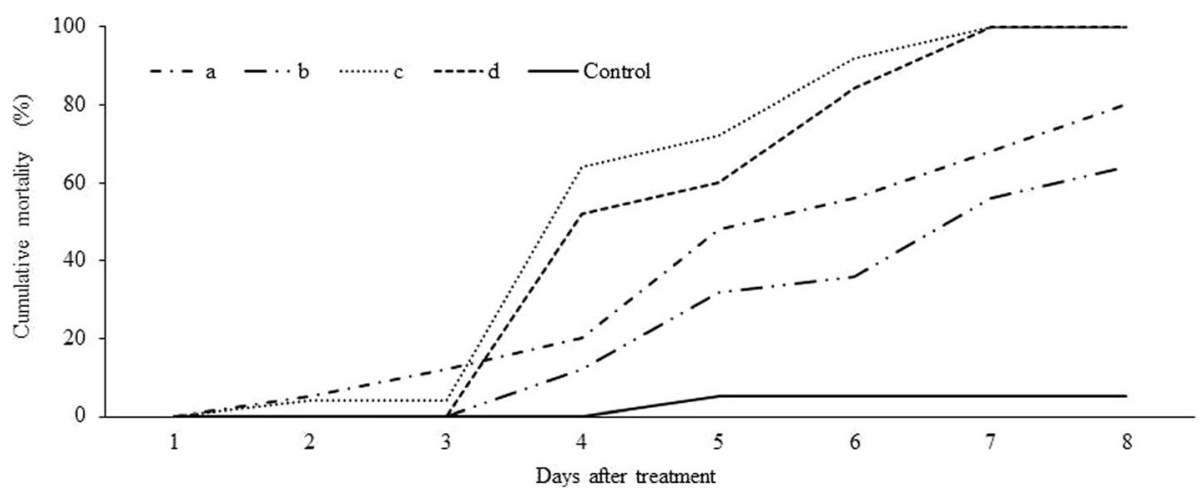

Fig. 1 Mortality rates of Xylosandrus germanus treated with Metarhizium anisopliae TR-106 at different methods and conidial concentrations. a $1 \times$

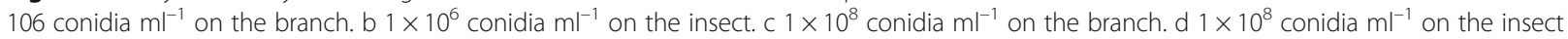

application on branches and direct on insects, respectively (Table 1 ).

On the 1st day after treatment, there was no mortality for TR-106 isolate in the 2 tested concentrations applied in the 2 methods (Fig. 1). In the 2 methods, mortality rates were low during the 1st 3 days but death increased after the 3rd day (Fig. 1). Meanwhile, the mortality rates of $X$. germanus treated with $1 \times 10^{6}$ conidia $\mathrm{ml}^{-1}$ of the isolate reached 80 and $64 \%$ at the end of the 8 th day on branches and directly on insects, respectively. The isolate caused $100 \%$ mortality rate at the end of the 8 th day in the 2 application methods with $1 \times 10^{8}$ conidia $\mathrm{ml}^{-1}$. Moreover, all applications of TR-106 isolate caused approximately $100 \%$ mycosis rate on dead adults of $X$. germanus.

The efficacy of B. bassiana (TR-217) used in this study was found to be lower than that of $M$. anisopliae (TR-106). The $\mathrm{LT}_{50}$ values of TR-217 isolate at $1 \times 10^{6}$ conidia $\mathrm{ml}^{-1}$ were 8.38 and 9.57 days, while the $\mathrm{LT}_{90}$ values were 16.78 and 20.30 days for treated branches and for application directly on the insects, respectively. Respective $\mathrm{LT}_{50}$ values for $1 \times 10^{8}$ conidia $\mathrm{ml}^{-1}$ of the isolate were 5.96 and 6.03 days, while they were 11.79 and 10.80 days for $\mathrm{LT}_{90}$ (Table 2).
The mortality rates when applied at $1 \times 10^{8}$ conidia $\mathrm{ml}^{-1}$ of $B$. bassiana recorded 64 and $80 \%$ at the end of the 8th day on treated branches and insects, respectively. However, the efficacy of $1 \times 10^{6}$ conidia $\mathrm{ml}^{-1}$ B. bassiana (TR-217 isolate) against the beetle was lower than those of the highest concentration used in the study of the 2 application methods (Fig. 2). The mortality rates of $X$. germanus females at $1 \times 10^{6}$ conidia $\mathrm{ml}^{-1}$ of B. bassiana remained around 40.0 and $45.0 \%$, even on the 8th day after treatment. Similar to M. anisopliae, $B$. bassiana isolate caused about $100 \%$ mycosis rate on females in all treatments.

$\mathrm{LT}_{50}$ and $\mathrm{LT}_{90}$ values of $M$. anisopliae (TR-106) and $B$. bassiana (TR-217) isolates decreased with increasing the conidial concentration at all applications. However, comparisons of the confidence intervals indicated insignificant differences between $\mathrm{LT}_{90}$ values at both concentrations of B. bassiana TR-217 isolate in the 2 application methods. The results of this study are in line with those of previous studies as many researchers have reported that efficacy of EPF increases according to concentration increase. Therefore, the $\mathrm{LT}_{50}$ and $\mathrm{LT}_{90}$ values of the fungi decreased (Kocaçevik et al. 2016 and Kushiyev et al. 2017, 2018). Kushiyev et al. (2017) found that $\mathrm{LT}_{50}$ and $\mathrm{LT}_{90}$ values of

Table 2 Probit analysis data on mortality time of Xylosandrus germanus females after applications of two conidial concentrations of Beauveria bassiana TR-217 isolate on hazelnut branches and beetle females

\begin{tabular}{|c|c|c|c|c|}
\hline \multirow[t]{2}{*}{ Variables } & \multicolumn{2}{|l|}{$1 \times 10^{6}$ conidia $\mathrm{ml}^{-1}$} & \multicolumn{2}{|l|}{$1 \times 10^{8}$ conidia $\mathrm{ml}^{-1}$} \\
\hline & On branch & On insect & On branch & On insect \\
\hline $\mathrm{LT}_{50}$ (95\% fiducial limit) & $8.38(7.17-11.50) a^{*}$ & 9.57 (7.84-15.56) a & $5.96(5.32-6.85) b$ & $6.03(5.41-6.87) b$ \\
\hline $\mathrm{LT}_{90}$ (95\% fiducial limit) & $16.78(12.02-37.58) \mathrm{a}$ & $20.30(13.37-63.78) a$ & $11.79(9.50-17.45)$ a & $10.80(8.91-15.38) a$ \\
\hline Slope \pm SE & $4.24 \pm 0.92 \mathrm{a}$ & $3.92 \pm 0.95 a$ & $4.32 \pm 0.69 a$ & $5.06 \pm 0.78 \mathrm{a}$ \\
\hline Regression equation & $y=-3.92+4.24 x$ & $y=-3.85+3.92 x$ & $y=-3.35+4.32 x$ & $y=-3.95+5.06 x$ \\
\hline$x^{2}$ & 36.89 & 23.95 & 29.61 & 40.78 \\
\hline$D_{f}$ & 38 & 38 & 38 & 38 \\
\hline Heterogeneity & 0.97 & 0.63 & 0.78 & 1.07 \\
\hline
\end{tabular}

*Within rows, means followed by the same lower case letters do not differ significantly 


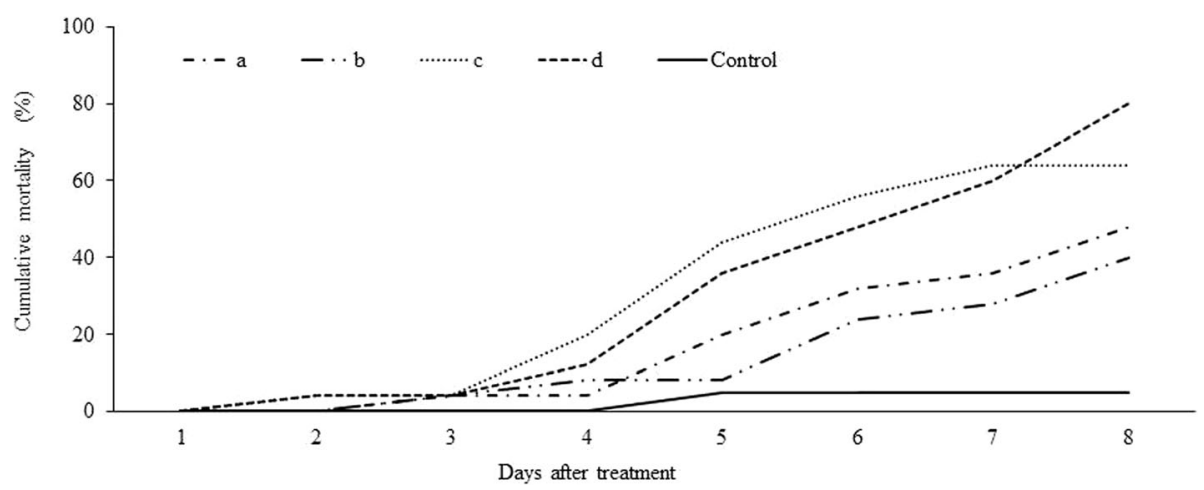

Fig. 2 Mortality rates of Xylosandrus germanus treated with Beauveria bassiana TR-217 at different methods and conidial concentrations. a $1 \times 10^{6}$

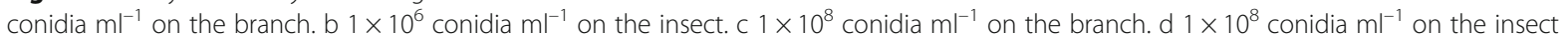

M. anisopliae TR-106 and B. bassiana TR-217 isolates applied to females of $A$. dispar decreased by increasing conidial concentration.

In the present study, there was insignificant difference between both application methods $(P>0.05)$ with regard to infectivity. Similarly, some researchers found insignificant differences in the mortality rates of $X$. glabratus females, treated with B. bassiana strain (GHA) and $I$. fumosorosea strains (Ifr 3581 and PFR), by dipping in fungal concentration or placing on treated avocado branches (Carrillo et al. 2015). In another study, Kushiyev et al. (2018) investigated the efficacy of I. fumosorosea TR-78-3 at $1 \times 10^{6}$ and $1 \times 10^{8}$ conidia ml ${ }^{-1}$ against females of $A$. dispar by treating the plant branches and direct spray on insects and found insignificant differences between the two application methods.

Liu et al. (2017) stated that B. bassiana (12,108 isolates) was more effective than M. anisopliae (3.4607 isolate) on adults of Curculio nucum (Coleoptera: Curculionidae). The difference between obtained results and that of Liu et al. (2017) may be derived from using different isolates. Consequently, the efficacy of EPF may vary between species, within a genus, and even between isolates of the same species (Goettel et al. 2005).

EPF can be effective when applied directly on insect pests or when they are later acquired by the insects from treated surface; therefore, ambrosia beetles, which spent the majority of their life cycles inside the host trees, are ideal target for EPF (Castrillo et al. 2013) and it can be observed lately that studies on ambrosia beetle-EPF interactions were increased. Commercial strains of B. bassiana (GHA and Naturalis) and $M$. brunneum (F52) applied on females of $X$. crassiusculus caused 77.96 and $79 \%$ mortality rate, respectively, on the 5th day after application under laboratory conditions, and also, the beetle females exposed to peach stems treated with the fungi had low survival capacity (Castrillo et al. 2013).

\section{Conclusion}

The present findings determined that EPF, $M$. anisopliae (TR-106) and B. bassiana (TR-217), seemed to be promising one of biological control agent against the invasive ambrosia beetle, $X$. germanus. However, further studies are necessary to evaluate the efficacy of the isolates on the treated pest under field conditions.

\section{Acknowledgements}

Rahman Kushiyev is thankful to the Scientific and Technological Council of Turkey (TUBITAK) for providing fellowship.

\section{Funding \\ No funding}

\section{Availability of data and materials}

The datasets used and/or analyzed during the current study are available from the corresponding author on reasonable request.

\section{Authors' contributions}

$C T, R K, I E, I O O$, and IS designed the study, supervised the work, and wrote the manuscript with input from all authors. CT, RK, IE, IOO, and IS carried out the experiments. CT analyzed the data. All authors read and approved the final manuscript.

Ethics approval and consent to participate Not applicable

\section{Consent for publication \\ Not applicable}

\section{Competing interests}

The authors declare that they have no competing interests.

\section{Publisher's Note}

Springer Nature remains neutral with regard to jurisdictional claims in published maps and institutional affiliations.

Received: 12 February 2019 Accepted: 12 April 2019

Published online: 08 May 2019

\section{References}

Ak K (2016) Comparison of sticky and non-sticky traps against harmful shothole borers (Coleoptera: Curculionidae: Scolytinae) in hazelnut orchards. Anadolu J Agric Sci 31(1):165-170 
Ak K, Saruhan I, Tuncer C, Akyol H, Kilic A (2011) Ambrosia beetles (Coleoptera: Scolytidae) species and their damage ratios in kiwi orchards of Ordu Province. Turk Bull Entomol 1(4):229-234

Arthurs SP, Bruck DJ (2017) Microbial control of nursery ornamental and landscape plant pests. In: Lacey LA (ed) Microbial control of pests. Elsevier, London, pp 355-365

Biedermann PHW (2007) Social behaviour in sib mating fungus farmers. M. Sc. Thesis. University of Berne, Berne, p 85

Carrillo D, Dunlap CA, Avery PB, Navarrete J, Duncan RE, Jackson MA, Behle RW, Cave RD, Crane J, Rooney AP, Peña JE (2015) Entomopathogenic fungi as biological control agents for the vector of the laurel wilt disease, the red bay ambrosia beetle, Xyleborus glabratus (Coleoptera: Curculionidae). Biol Control 81:44-50

Castrillo LA, Griggs MH, Vandenberg JD (2013) Granulate ambrosia beetle, Xylosandrus crassiusculus (Coleoptera: Curculionidae), survival and brood production following exposure to entomopathogenic and mycoparasitic fungi. Biol Control 67:220-226

Dhingra OD, Sinclair JB (1995) Basic plant pathology methods, vol 62, 2nd edn. CRC Press, Boca Raton, p 751

Goettel MS, Eilenberg J, Glare T (2005) Entomopathogenic fungi and their role in regulation of insect populations. In: Gilbert LI, latrou K, Gill SS (eds) Comprehensive Molecular Insect Science. Elsevier, Amsterdam, pp 361-405

Hulcr J, Dunn RR (2011) The sudden emergence of pathogenicity in insect fungus symbioses threatens naive forest ecosystems. Proc R Soc Lond B 278: 2866-2873

Humber RA (1997) Fungi: Identification. In: Lacey L (ed) Manual of Techniques in Insect Pathology. Academic Press, London, pp 153-185

Knížek M (2011) Scolytinae. In: Löbl I, Smetana A (eds) Catalogue of Palaearctic Coleoptera, vol 7. Apollo Books, Stenstrup, pp 204-251

Knížek M, Beaver RA (2007) Taxonomy and systematics of bark and ambrosia beetles. In: Lieutier et al (eds) Bark and Wood Boring Insects in Living Trees in Europe. A Synthesis, pp 41-54

Kocaçevik S, Sevim A, Eroğlu M, Demirbağ Z, Demir I (2016) Virulence and horizontal transmission of Beauveria pseudobassiana S.A. Rehner \& Humber in Ips sexdentatus and Ips typographus (Coleoptera: Curculionidae). Turk J Agric For 40:241-248

Kushiyev R, Tuncer C, Erper I, Ozdemir 1O, Saruhan I (2018) Efficacy of native entomopathogenic fungus, Isaria fumosorosea, against bark and ambrosia beetles, Anisandrus dispar Fabricius and Xylosandrus germanus Blandford (Coleoptera: Curculionidae: Scolytinae). Egypt J Biological Pest Control 28:55

Kushiyev R, Tuncer C, Erper I, Saruhan I (2017) Effectiveness of entomopathogenic fungi Metarhizium anisopliae and Beauveria bassiana against Anisandrus dispar (Coleoptera: Curculionidae: Scolytinae). IX. International Hazelnut Congress Abstract Book. 15-19 August, Samsun, p 178

Liu J, Zhang Y, Liu T, Tuncer C, Cheng Y (2017) Screening of a highly pathogenic strain against hazelnut weevil and microscopic observation on its infection process. J Beijing Forestry Univ 39(3):32-37

Ranger CM, Reding ME, Schultz PB, Oliver JB, Frank SD, Addesso KM, Chong JH, Sampson B, Werle C, Gill S, Krause C (2016) Biology, ecology, and management of non-native ambrosia beetles (Coleoptera: Curculionidae: Scolytinae) in ornamental plant nurseries. J Integr Pest Manag 7(1):1-23

Robertson JL, Russell RM, Preisler HK, Savin E (2007) Bioassays with arthropods, Second edn. CRC Press, USA, Floride, p 199

Roy HE, Steinkraus DC, Eilenberg J, Hajek AE, Pell JK (2006) Bizarre interactions and endgames: entomopathogenic fungi and their arthropod hosts. Annu Rev Entomol 51:331-357

Samson RA, Evans HC, Latge JP (1988) Atlas of entomopathogenic fungi. Springer Verlag, Berlin, p 187

Zimmermann G (2007a) Review on safety of the entomopathogenic fungi Beauveria bassiana and Beauveria brongniartii. Biocontrol Sci Tech 17:553-596

Zimmermann G (2007b) Review on safety of the entomopathogenic fungus Metarhizium anisopliae. Biocontrol Sci Tech 17:879-920

Zimmermann G (2008) The entomopathogenic fungi Isaria farinosa (formerly Paecilomyces farinosus) and the Isaria fumosorosea species complex (formerly Paecilomyces fumosoroseus): biology, ecology and use in biological control. Biocontrol Sci Tech 18:865-901

\section{Submit your manuscript to a SpringerOpen ${ }^{\odot}$ journal and benefit from:}

- Convenient online submission

- Rigorous peer review

- Open access: articles freely available online

- High visibility within the field

- Retaining the copyright to your article

Submit your next manuscript at $\boldsymbol{\nabla}$ springeropen.com 